\section{FRI0291 RENAL TRANSPLANTATION DUE TO RAPIDLY PROGRESSIVE GLOMERULONEPHRITIS (RPGN) COMPARATIVE STUDY WITH NON-AUTOIMMUNE TRANSPLANTATION AND LONG-TERM FOLLOW-UP. STUDY FROM A SINGLE TERTIARY CENTER}

Lara Sánchez Bilbao ${ }^{1}$, Marina de Cos-Gómez ${ }^{2}$, Iñigo González-Mazón ${ }^{1}$, Belén Atienza-Mateo ${ }^{1}$, José Luis Martín-Varillas ${ }^{1}$, Monica Calderón-Goercke ${ }^{1}$, D. Prieto-Peña ${ }^{1}$, Juan Carlos Ruiz-San Millán², Miguel Á. González-Gay ${ }^{1}$, Ricardo Blanco ${ }^{1} .{ }^{1}$ Rheumatology. Hospital Universitario Marqués de Valdecilla, IDIVAL., Santander, Spain; ${ }^{2}$ Nephrology. Hospital Universitario Marqués de Valdecilla, IDIVAL., Santander, Spain

Background: Rapidly Progressive Glomerulonephritis (RPGN) is characterized histology by the presence of crescents and clinically by a rapid and severe decline in kidney function. Thus, this entity may lead to an end stage renal disease, with kidney transplantation. RPGN can be primary, without extra-renal involvement (RPGN-renal-limited), or secondary to systemic autoimmune disorders (RPGN-SAD), infectious diseases or drugs. Kidney transplantation in RPGN-SAD may be associated to a worse outcome.

Objectives: In a series of patients with first transplantation due to RPGN our aim was to assess a) long-term post-transplant survival in RPGNSAD, b) comparison of post-transplant survival between RPGN-SAD and RPGN-renal-limited and c) comparison of both RPGN (SAD and renal-limited) with a control group of non-immunological disorder, the polycystic kidney disease (PCKD).

Methods: We study three groups of patients: a) RPGN-SAD due to granulomatosis with polyangiitis $(n=3)$, microscopic polyangiitis $(n=6)$ or Goodpasture syndrome $(n=2)$, b) RPGN-renal-limited and c) control group of patients with PCKD. All these patients were transplanted in a single reference University Hospital. The main outcome variables were a) graft and patient survival up to 20 years and b) evolution of renal function (serum creatinine and proteinuria) in the first 5 years of follow-up. Cumulative survival rates after transplantation were estimated by the KaplanMeier method and compared between groups using the log-rank test. Kruskal-Wallis test was used to compare quantitative variables and $\mathrm{chi}^{2}$ I Fisher's exact test for qualitative variables.

Results: We included a total of 100 patients with renal transplant; a) RPGN-SAD group $(n=11)$, b) RPGN-renal-limited group ( $n=32)$, and $c)$ PCKD group $(n=57)$. No significant differences at baseline were observed between the two RPGN groups regarding sex, age and cardiovascular risk factors. Compared to the PCKD group, patients with RPGN presented higher cholesterol levels at the time of the transplant $(p=0.041)$ with no other significant differences. Renal biopsy had been performed in the 43 patients with RPGN: type I (27.9\%), type II (4.7\%), type III RPGN (41.9\%) and $25.6 \%$ of patients had not classified RPGN (no immunofluorescence was performed at the time of the biopsy). From 89 patients (of 100) in which a renal biopsy was performed during the firstyear post-transplant, rejection was found in 33 patients $(37.1 \%)$ without significant differences between the 3 groups $(5$ cases in the RPGN-SAD group, 11 cases in the RPGN-renal-limited group and 17 cases in the PCKD group; $p=0.592$ ). The evolution of serum creatinine and the proteinuria after the transplant is shown in TABLES 1-2. There were no significant differences between the three groups in the serum creatinine values during at 1st, 6th, 12th, 36th and 60th months post-transplant. Neither differences were found in terms of graft and patient survival between the 3 groups in 20 years of follow-up (Figures 1 and 2).

Conclusion: Our study shows similar graft and patient survival as well as renal outcome in renal transplant due to RPGN-SAD and RPGN-renal-limited. These outcomes were also similar in non-immune renal disease. Therefore, renal transplantation could be the best option for patients with end stage renal disease due to RPGN regardless of systemic manifestations.
Table 1. Evolution of creatinine and proteinuria levels after renal transplant in RPGN and PCKD.

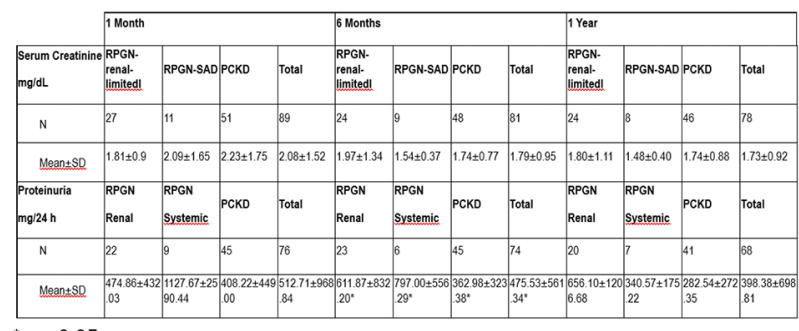

${ }^{*} \mathrm{p}<0.05$

Table 2.

\begin{tabular}{|c|c|c|c|c|c|c|c|c|}
\hline \multirow[b]{2}{*}{$\begin{array}{l}\text { Serum Creatinine } \\
\mathrm{mg} / \mathrm{dL}\end{array}$} & \multicolumn{4}{|l|}{3 Years } & \multicolumn{4}{|l|}{5 Years } \\
\hline & $\begin{array}{l}\text { RPGN- } \\
\text { renal- } \\
\text { limitedl }\end{array}$ & RPGN-SAD & PCKD & Total & $\begin{array}{l}\text { RPGN- } \\
\text { renal- } \\
\text { limitedl }\end{array}$ & RPGN-SAD & PCKD & Total \\
\hline $\mathrm{N}$ & 20 & 9 & 41 & 70 & 14 & 10 & 36 & 60 \\
\hline Mean $+\mathrm{SD}$ & $1.69 \pm 0.76$ & $1.70 \pm 0.69$ & $1.69 \pm 0.91$ & $1.69 \pm 0.83$ & $1.64 \pm 0.80$ & $1.81 \pm 0.99$ & $1.82 \pm 1.29$ & $1.77 \pm 1.13$ \\
\hline $\begin{array}{l}\text { Proteinuria } \\
\mathrm{mg} / 24 \mathrm{~h}\end{array}$ & $\begin{array}{l}\text { RPGN } \\
\text { Renal }\end{array}$ & $\begin{array}{l}\text { RPGN } \\
\text { Systemic }\end{array}$ & PCKD & Total & $\begin{array}{l}\text { RPGN } \\
\text { Renal }\end{array}$ & $\begin{array}{l}\text { RPGN } \\
\text { Systemic }\end{array}$ & PCKD & Total \\
\hline $\mathrm{N}$ & 19 & 7 & 40 & 66 & 13 & 8 & 31 & 52 \\
\hline Mean \pm SD & $\begin{array}{l}510.79+832 \\
.90\end{array}$ & $\begin{array}{l}272.57+291 \\
20\end{array}$ & $\begin{array}{l}340.65 \pm 344 \\
.17\end{array}$ & $\begin{array}{l}482.41 \pm 527 \\
.44\end{array}$ & $\begin{array}{l}238.23 \pm 311 \\
19\end{array}$ & $\begin{array}{l}443.88 \pm 300 \\
.87\end{array}$ & $\begin{array}{l}579.26 \pm 111 \\
4.5\end{array}$ & $\begin{array}{l}473.17 \pm 88 \\
.08\end{array}$ \\
\hline
\end{tabular}

\begin{tabular}{|c|c|c|c|c|c|c|c|c|}
\hline \multirow[b]{2}{*}{$\begin{array}{l}\text { Serum Creatinine } \\
\mathrm{mg} / \mathrm{dL}\end{array}$} & \multicolumn{4}{|l|}{3 Years } & \multicolumn{4}{|l|}{5 Years } \\
\hline & $\begin{array}{l}\text { RPGN- } \\
\text { renal- } \\
\text { limitedl }\end{array}$ & RPGN-SAD & PCKD & Total & $\begin{array}{l}\text { RPGN- } \\
\text { renal- } \\
\text { limitedl }\end{array}$ & RPGN-SAD & PCKD & Total \\
\hline $\mathrm{N}$ & 20 & 9 & 41 & 70 & 14 & 10 & 36 & 60 \\
\hline Mean $+S D$ & $1.69 \pm 0.76$ & $1.70 \pm 0.69$ & $1.69 \pm 0.91$ & $1.69 \pm 0.83$ & $1.64 \pm 0.80$ & $1.81 \pm 0.99$ & $1.82 \pm 1.29$ & $1.77 \pm 1.13$ \\
\hline $\begin{array}{l}\text { Proteinuria } \\
\mathrm{mg} / 24 \mathrm{~h}\end{array}$ & $\begin{array}{l}\text { RPGN } \\
\text { Renal }\end{array}$ & $\begin{array}{l}\text { RPGN } \\
\text { Systemic }\end{array}$ & PCKD & Total & $\begin{array}{l}\text { RPGN } \\
\text { Renal }\end{array}$ & $\begin{array}{l}\text { RPGN } \\
\text { Systemic }\end{array}$ & PCKD & Total \\
\hline$N$ & 19 & 7 & 40 & 66 & 13 & 8 & 31 & 52 \\
\hline Mean_SD & $\begin{array}{l}510.79 \pm 832 \\
.90\end{array}$ & $272.57 \pm 291$ & $\begin{array}{l}340.65 \pm 344 \\
.17\end{array}$ & $\begin{array}{l}382.41 \pm 527 \\
.44\end{array}$ & $\begin{array}{l}238.23 \pm 311 \\
.19\end{array}$ & $\begin{array}{l}443.88 \pm 30 \\
.87\end{array}$ & $\begin{array}{l}579.26 \pm 111 \\
4.5\end{array}$ & $\begin{array}{l}473.17 \pm 887 \\
.08\end{array}$ \\
\hline
\end{tabular}

Figure 1. Patient survival.

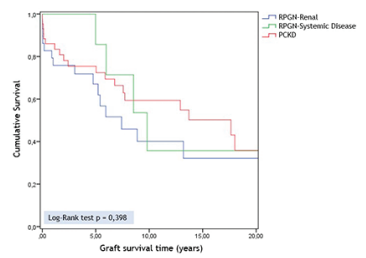

Figure 2. Graft survival.

Disclosure of Interests: Lara Sánchez Bilbao: None declared, Marina de Cos-Gómez: None declared, Iñigo González-Mazón: None declared, Belén Atienza-Mateo: None declared, José Luis Martín-Varillas: None declared, Monica Calderón-Goercke: None declared, D. Prieto-Peña: None declared, Juan Carlos Ruiz-San Millán: None declared, Miguel Á. González-Gay: None declared, Ricardo Blanco Grant/research support from: Abbvie, MSD, and Roche, Consultant for: Abbvie, Pfizer, Roche, Bristol-Myers, Janssen, Speakers bureau: Abbvie, Pfizer, Roche, Bristol-Myers, Janssen DOI: 10.1136/annrheumdis-2019-eular.1961 